\title{
Acquiring High to Ultra-High Resolution Geological Records of Past Climate Change by Scientific Drilling
}

\author{
by Juergen Thurow, Larry C. Peterson, Ulrich Harms, David A. Hodell, Heather \\ Cheshire, Hans-Juergen Brumsack, Tomohisa Irino, Michael Schulz, \\ Valerie Masson-Delmotte, and Ryuji Tada
}

doi:10.2204/iodp.sd.8.08.2009

\section{Introduction and Workshop Goals}

Scientific drilling on land and sea has played a key role in advancing our knowledge of climate change. It has helped to demonstrate the effects of orbital variations on climate, revealed evidence for extreme warm events in the past and for the timing of Antarctic ice growth, and provided insights into the hydrologic balance of lake systems around the world. Now, with attention increasingly focused on the likely manifestation of future climate change, the challenge to under- stand past climates at societally relevant, high-resolution timescales has become ever more critical. Sediments and other archives that preserve climate information on timescales approaching those of instrumental records have much to offer to our understanding of how the climate system works (Fig. 1). These records, ideally with a sub-annual to centennial resolution, provide a unique opportunity to evaluate the global operation of the ocean-continent-atmosphere system on human timescales and to appraise the relative importance of each part of the system.

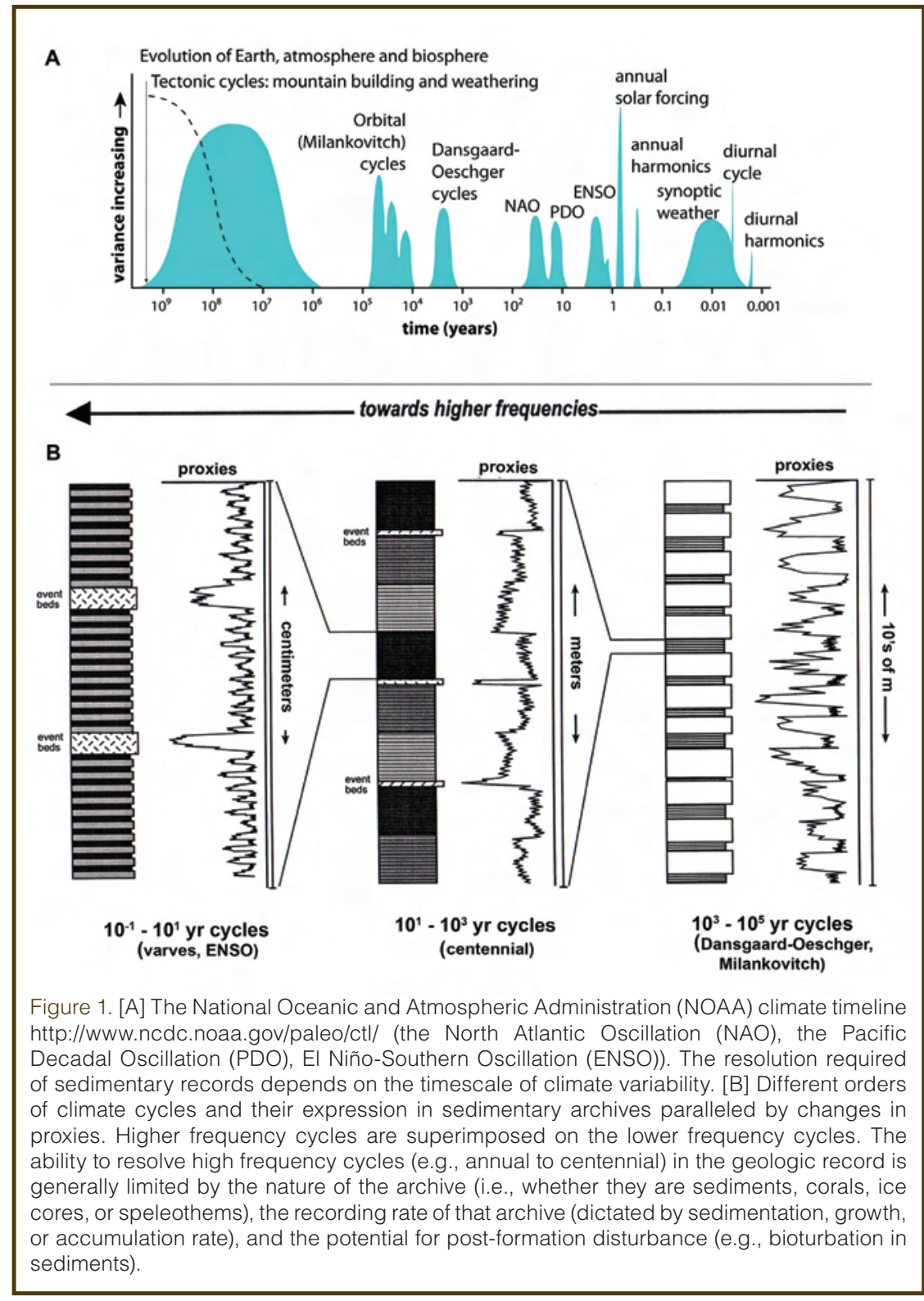

Long high-resolution records of excellent quality acquired through ocean drilling have contributed significantly to our current understanding of climate (Ocean Drilling Program (ODP) Site 893, Santa Barbara Basin, California [Behl and Kennett, 1996; Hendy and Kennett, 2000]; ODP Site 1002, Cariaco Basin [Peterson et al., 2000; Hughen et al., 2004]). Comparable-resolution records recovered from lake drilling (Hodell et al., 2008; Scholz et al., 2007) and analyses of speleothems (Wang et al., 2001) have significantly enhanced the climate "portfolio" (Fig. 2). However, the existing inventory of high-resolution records generated by scientific coring and drilling in the oceans and on land (including ice) is currently limited in both number and global coverage (Voelker, 2002; Clement and Peterson, 2008). The acquisition and analysis of many more detailed multi-proxy records of past environmental conditions from all areas of Earth are needed to allow researchers to better understand why and how the climate system responds rapidly to external and internal forcing and how the various high-frequency oscillations of the climate system interact over longer time intervals.

A group of sixty-four international scientists-experts in the fields of marine, terrestrial, ice-cores and Earth-system modeling-met at the German Research Centre for Geosciences (GFZ), Potsdam, from 29 September through 1 October 2008, with the objective of identifying key climate 
questions best addressable with high- to ultra-high resolution records and designing scientific drilling strategies to recover them. The workshop was initiated and funded by the Integrated Ocean Drilling Program (IODP) and the International Continental Drilling Program (ICDP). Its primary aim was to find and/or explore key areas with potentially high-resolution records, in order to coordinate and integrate existing proposals from within IODP/ICDP and from other scientific programs and to develop new drilling proposals incorporating the objectives outlined in this workshop summary. The ultimate goal was to identify a global array of potential coring sites spanning different time intervals to fully understand the causes and consequences of rapid environmental/climate change.

The workshop opened with an invited series of keynote presentations designed to summarize our current understanding of climate change on sub-millennial timescales and to high-light recent advances and outstanding scientific issues. This was followed by talks that focused on the scientific missions, program structure, and proposal submission and review process for ICDP and IODP, and by short statements from all of the workshop participants about their research interests. A complete list of speakers and topics can be found on the workshop website (http://www.iodp.org/ climate-ws-workshop/ Based on break-out group discussions, five overlapping climate themes emerged that are graphically represented by the petals of the flower diagram in Fig. 3. The interrelated petals are the main drivers of climate variability and, as such, form and inform the questions that can be addressed by high-resolution records. Within each of these themes, the nature and origin of abrupt climate change form a common thread.

\section{Understanding the Causes and Consequences of Climate Variability}

\section{Climate Modes}

High-resolution sedimentary archives from ocean and terrestrial systems provide a means of tracking climate variability throughout much of the globe at interannual to decadal to centennial/millennial timescales. They can be used to study past variability in the most important elements of the modern climate system, such as the El Niño-Southern Oscillation (ENSO), monsoons, the North Atlantic Oscillation (NAO), the Pacific Decadal Oscillation (PDO), the Arctic Oscillation (AO), and the Southern Annular Mode (SAM) (Fig. 1). Each of these modes or elements has been defined using instrumental climate and weather data, yet little is known about centers of action or centers of impact and about how these modes may have varied in the past under different boundary conditions.

Sedimentary archives can provide us not only with high fidelity records of past climate mode behavior-such as the millennial record of ENSO from its source region in the western Pacific (Tudhope et al., 2001) — but also with records of their teleconnected impacts around the globe (Wang et al., 2006). In this way, questions can be answered regarding the stationarity of ENSO-associated droughts or PDO-associated changes in North American temperature or snowfall (Mantua and Hare, 2002). Accordingly, the Potsdam Workshop identified as high priority for both IODP and ICDP the development of a series of climate mode reference sections

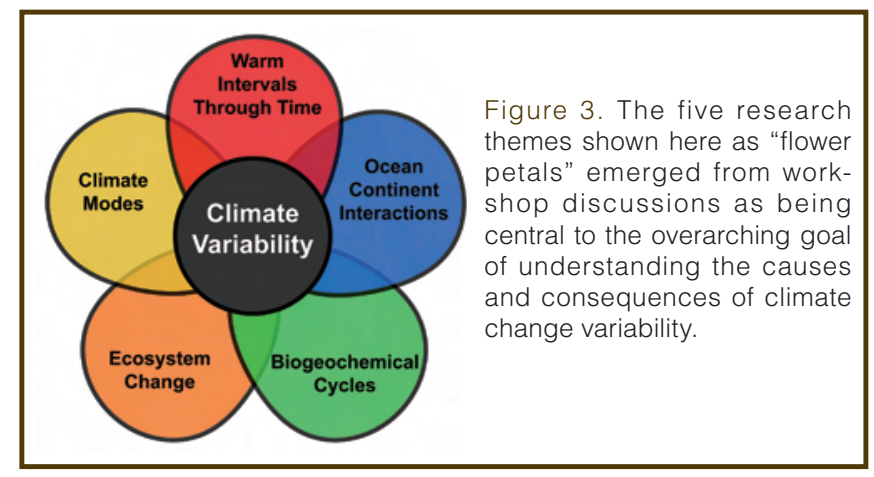


as well as response records from key parts of the globe. One suggestion was to focus on establishing the record of past variability in the global Walker Circulation (the zonal atmospheric overturning circulation that drives ENSO) as well as African and Asian monsoons. In the case of the Walker Circulation and ENSO, the acquisition of records that span the tropical Pacific from west (e.g., Papua New Guinea) to east (potentially Galapagos) should be a goal, as well as in regions that today show evidence of strong teleconnections, such as Ecuador, Peru, northeast Brazil, and South Africa. Combined with a similar latitudinal transect of high-resolution lake records from the western Americas, it should be possible to begin sorting out the relative forcing of ENSO as compared to such phenomena as latitudinal shifts in zonal circulation and changes in tropical convection.

During the last glacial period, the rapid temperature excursions over Greenland that have come to be known as Dansgaard-Oeschger events (Dansgaard et al., 1984, 1993) define a mode of climate variability that is critical to understand. The excursions appear to have a global imprint, though many regions are greatly undersampled (e.g., the Southern Hemisphere), and improved knowledge is needed of the spatial and temporal expression of these events. Their signature often seems to be manifested in variables other than temperature-for example, shifts in tropical rainfall patterns (Clement and Peterson, 2008). Abrupt, rapid climate change of this type, were it to occur in the future, could potentially put modern society under extreme stress. An urgent need exists to identify the 'symptoms'-the concatenation of events-that lead to the threshold of Earth's climate becoming markedly hotter or colder over the course of a decade or two. Paleoclimate records have revealed evidence of stressed ecosystems that are in disequilibrium during times of rapid climate change, with commonplace local extinctions. Future climate events have the potential to affect millions of people, most probably by disruption of the food chain or water supplies.

Geologic archives that preserve and can be sampled at high temporal resolution will help us answer questions about climate modes and abrupt change such as the following: What is the climate sensitivity to natural forcing, and how will anthropogenic actions influence this sensitivity? What changes might we expect in the Walker Circulation in the (warmer) years ahead? How variable can ENSO be? Is millennial variability present that shows ENSO patterns? What happened to ENSO during times of Pliocene warmth? Is there a real decadal mode in the Pacific? Is the PDO a distinct and separate element of the climate system? What is the role of the meridional overturning circulation (MOC) in the climate system on timescales ranging from decadal to millennial (Keenlyside et al., 2008; Stanford et al., 2006)? Is there a relation between the MOC and AO? Can sediment records be used to establish a definitive link between high latitude sea ice and the mean position of the Intertropical Convergence Zone (ITCZ) (Broecker, 2006)?

A number of strategies and data needs were identified to quantify conditions contributory to abrupt climate change in the late Quaternary. These include the development of proxies and drilling targets for reconstruction of sea-ice variability on various timescales; evaluating the sensitivity of ice sheets and sea level to past climate change to answer such questions as whether the West Antarctic Ice Sheet collapsed during previous interglacials; and examining whether inter-hemispheric phase-relationships known in the $100-k y r$ world were the same as earlier in the Pleistocene in the 41-kyr world.

\section{Warm Intervals through Time}

The most recent Intergovernmental Panel on Climate Change Report (IPCC, 2007) predicted that present and near-future global warming will produce boundary conditions very different from those of the last two million years; however, there is currently no clearly identifiable analogue for either the present interglacial or for anthropogenic climate warming. Models suggest that the Greenland Ice Sheet and perhaps portions of the West Antarctic Ice Sheet will begin to disappear as global climate warms (Gregory et al., 2004; Hu et al., 2009), but we don't really know if this happened previously within the warmest intervals of the late Quaternary. How sensitive were ice sheets (and sea level) to past climate change, especially during periods warmer than today (e.g., Marine Isotope Stages 5e, 11, 31)? What were the rates of change? Did the West Antarctic Ice Sheet collapse during previous interglacials?

Interglacial periods can be regarded as anomalies within the climate norm of the 100-kyr glacial cycles, which display the classic sawtooth pattern of abrupt beginnings that gradually subside towards the background norm (Fig. 4). Each interglacial is unique, and as such none can be used as a perfect analogue for the continued evolution of the present interglacial or for future climate change. One possible strategy is to compare all late Quaternary interglacials to generate 'an ideal interglacial' and a model for end-member states (Ruddiman, 2005). Re-examination of extant material and drilling a dedicated array of widely spaced high-resolution records are useful means of achieving this. Since oceans are buffers of climate change and lakes are amplifiers, transects of both marine and terrestrial records are prerequisites for achieving a complete picture of the patterns and magnitude of interglacial warmth.

Though it is natural to focus on recent interglacials because of the similarities in non-anthropogenic forcing, much can be learned from the study of older but more extreme warm intervals in Earth's history. Can extreme warm events like those of the mid-Cretaceous (Wilson and Norris, 2001) and the Paleocene-Eocene Thermal Maximum 
(PETM; Zachos et al., 2005; Weijers et al., 2007) be used to make predictive models that are of value today? Were other forcing mechanisms that are not known today operative in those events? These extreme departures from 'background' climate should be manifested in high-resolution records of the hydrologic cycle (Kraus and Riggins, 2007), atmos-pheric and oceanic circulation, and vegetation dynamics on land. A concerted and coordinated effort to examine time-equivalent studies over the widest possible geographical range is one approach to globally quantifying the precursor conditions and effects of these extreme warm events themselves.

\section{Ocean-Continent Interactions}

IODP and ICDP can make significant potential contributions to understanding past climate variability connected to the Ocean-Continent Interactions theme. This theme is as broad as it is central to human societies. For example, regional sea-surface temperature variability fundamentally affects heat and moisture supplies to nearby continents ("upstream" effects) (Shanahan et al., 2009), such as in the major low-latitude monsoon systems. Understanding monsoon dynamics under different climate regimes (Wang et al., 2005) is of critical impor-



Figure 4. A one million year comparison of ice core and marine core data to a terrestrial record of pollen variability from Lake Tenaghi Philippon, Greece. (A) $\delta D$ temperature proxy from Epica Dome C ice core, Antarctica (EPICA Community Members, 2004); (B); EPICA Dome C record of atmospheric methane concentrations (Loulergue etal., 2008); (C) percentages of arboreal pollen in sediments from Lake Tenaghi Philippon, Greece (Tzedakis et al., 2006); (D) composite benthic foraminiferal $\delta^{18} \mathrm{O}$ proxy for global ice volume variations, with glacial marine isotope stages labelled as 2 to 26 (Liesecki and Raymo, 2005). Note that the pollen record shows clear evidence of orbital and sub-orbital scale vegetation responses to Quaternary climate change and illustrates the potential for recovering long, continuous sediment sequences in lacustrine settings. tance because a significant fraction of the human

population depends on the monsoons and their life-giving rains for survival. Furthermore, investigating the interrelationships between climate, biotic evolution, and human cultural development will continue to define the effects of abrupt climate change (including droughts and floods) on life (Bartov et al., 2003; Haug et al., 2003; deMenocal, 2004). On the continents, "downstream" effects such as changes in continental weathering, hydrologic balance, and vegetation response can be reconstructed based on terrestrial archives such as lakes (Baker et al., 2001; Cheddadi et al., 2005). Oceanic archives recovered adjacent to the continents also record the direct influence of continental inputs, such as sediment from rivers and winds, and nutrients that play an important role in near-coastal bioproductivity and biogeochemical cycling (Mulitza et al., 2008).

Ocean-continent interactions in the high latitudes have been shown to have far-reaching effects on climate variability on all timescales. Investigating the extent of continental ice sheets, timing of ice sheet ablation, and relationships between Northern Hemisphere and Southern Hemisphere high-latitude climate (European Project for Ice Coring in Antarctica (EPICA) Community Members, 2006) are fundamental to understanding the role of the oceans and ice sheets in abrupt climate change. These studies depend on improved proxies of ice sheet dynamics, sea-ice, meltwater input, and sediment provenance, among others. Furthermore, scientific drilling has just begun to elucidate the connections betweenhigh-latitudeclimateandlow-latitudehydrology-for instance, the teleconnections between sea ice and monsoons or sea ice and the position of the ITCZ (Broecker, 2006).

One challenge the community will face in these efforts is the difficulty of finding paired ocean and continent archives in appropriate locations and with adequate resolution to investigate upstream and downstream processes. Nevertheless, new opportunities for enhancing the study of ocean-continent linkages are emerging from the recent integration of novel proxies for continental hydrology and vegetation (e.g., elemental ratio data in bulk sediments, molecular and isotopic composition of leaf waxes; Schefuss et al., 2005; Huang et al., 2007) with classic proxies such as dust, pollen, and clay mineralogy, which can be found in both oceanic and continental archives. Accordingly, workshop participants specifically recommended that scientific drilling proposals on ocean-continent interactions be solicited that focus on three broad topics of critical interest: (1) the major low-latitude monsoons, (2) the hydrologic balance in continental regions critical for human societies, and (3) ice sheet dynamics (Clarke, 2005), all of which will enhance understanding of abrupt climate change. 


\section{Biogeochemical Cycles}

The cycling of biogenic and geochemical fluxes has important effects on all Earth systems. However, the large number of unknowns associated with these cycles must be addressed at the highest possible resolution if past climate changes and all their complexities are to be correctly evaluated and future changes realistically predicted. We should know what role changes in the carbon cycle played as forcing or feedback during past climate changes (Cao and Woodward, 1998). In the endeavor to find analogues and to produce predictive models for ongoing climate warming, questions have to be addressed about the biotic response to ocean acidification (Fabry et al., 2008), the range of glacial-interglacial $\mathrm{CO}_{2}$ variability, and the controls on atmospheric greenhouse gas composition as recorded in ice cores.

The employment of high-resolution sedimentary records in these contexts has great strengths and advantages; not only does high-resolution sampling more accurately reveal the details and complexities of the system (e.g., better definition of the climate norm and anomalies), but it is also more likely to yield un-aliased climate signals. In order to understand the specific workings of the climate system under different boundary conditions, we must undertake investigations of the carbon cycle using well-dated, well-calibrated, high-resolution records. Fundamental questions that remain to be answered include the following: What is the role of the carbon cycle in the transition from 41-kyr to 100 -kyr cycles in the mid-Pleistocene (Fig. 4; Bintanja and van de Wal, 2008)? What is the role of ocean circulation in the carbon cycle, and how does carbon storage affect the cycle? What is the impact of carbon storage on metal cycles, and how useful are non-traditional metal isotope systems for tracing global paleoenvironmental change? What affects the $\mathrm{CO}_{2}$ exchange between the surface ocean and the atmosphere on different timescales (Bender et al., 1994)? Is there a threshold level of $\mathrm{CO}_{2}$ when the oceans switch to a different mode? In addition, the higher frequency behavior of the carbon cycle during the extreme warm climates of the mid-Cretaceous and PETM should be investigated at the highest possible resolution in order to gain insights into the possible extremes of our future world.

\section{Ecosystem Change and Biodiversity}

The resilience of ecosystems to climate change is of critical importance in the face of projected warming and altered precipitation regimes (Cramer et al., 2001; Parmesan, 2006). Determining whether systems bend or break under climate loading and where tipping points occur from one state to another can be profitably investigated through high-resolution paleoclimatic records. Indeed, a critical insight into paleoclimates is that they behave non-linearly, with sudden changes of direction. Determining the ecosystem impact of such events will require improved understanding of taphonomy, higher taxonomic resolution (possibly DNA-based identifications), and finer temporal resolution sampling than has commonly been applied, especially in terrestrial sequences. Long, high-resolution terrestrial records of past climate variability comparable to those of marine and ice cores must be studied (Fig. 4; Tzedakis et al., 2006). The 1-Myr-long record from tropical Lake Bosumtwi (Koeberl et al., 2007) and the 3-Myr record from the arctic Lake El'gygytgyn (Brigham-Grette et al., 2007) are outstanding examples that such archives can be found.

The impact on ecosystems of the arrival of new agents of change-such as humans or fire, or the cascading consequences of extinctions and immigrations-are additional issues that need to be resolved. Because terrestrial ecosystems are where people live, work, and generate the majority of global income, it is essential that their responses to climate change are understood and, if possible, anticipated.

\section{Towards The Development of Synergies and Strategies}

Other important discussions at the workshop focused on the practicalities of adopting a synergistic approach to climate research and of how to improve present techniques and develop new ones. There were strong feelings in common among the participants that a more tightly coordinated collaboration between paleoceanographers, terrestrial paleoclimatologists, paleoglaciologists, and modelers is required for climate change science to move beyond incremental advances.

There was lively debate about the nature and quality of the various proxies used to infer past climatic and oceanographic conditions. People acknowledged that there needs to be a more universal understanding of the limitations of proxies specific to each segment of the paleoclimate community in order to improve the correlation and synthesis of existing and future records. In particular, proxy development should focus on providing more quantitative data for climate modeling. Existing proxies need to be re-examined; we have the capacity to measure/analyze an ever-widening suite of sediment parameters, but do we always know what they mean/represent?

It is clear that there is a different culture of sampling between the ice core and marine/terrestrial communities. The latter tend to divide a core in time, while ice core groups tend to take each sample and divide it among multiple investigators. In order to maximize the information gained, highly coordinated research efforts are needed that focus on multiple proxies. In the future, cooperating groups will need to acquire more sediment than is presently considered necessary to allow for the many proxies now possible to analyze. This could be achieved by drilling wider diameter cores and/or additional parallel holes. Close coordination 
between separate investigating groups (e.g., shipboard versus non-shipboard) needs to be established early in the process of planning for drilling projects. In addition, the widest possible range of questions that could be addressed by analyzing the sediment should be considered right from the start, and thus the planning requirements of each potential investigating group could be met. This type of forward planning will be necessary to achieve coordinated temporal and spatial arrays.

To the extent that existing material from previously drilled sites is available, these archives should be used when practical to address new problems and/or apply new techniques whose development postdates the drilling and first wave of science to emerge. With regards to the acquisition of new sediment, core quality is critical. Scientific drilling has gone on long enough that many individuals with longstanding experience have moved on or retired. To avoid costly mistakes and wasted time, records of how best to core particular types of sediments should be kept so that this experience is not lost.

The continuing improvement of standard chronological techniques and the development of new methods are necessary prerequisites to producing high quality high-resolution climate records. Ideally, chronologies should be absolute, as can be achieved by the counting of annual layers in ice cores or distinct varves in lacustrine or marine sediments. In the absence of absolute age control, dating is usually based on a combination of techniques including radiocarbon, foraminiferal oxygen isotope stratigraphies (in marine sequences), paleomagnetism, and tephrochronology. In addition, new techniques that are under development include exposure dates on tufa (Rich et al., 2003); optically stimulated luminescence (OSL) dating at millennial resolution (Stevens et al., 2007); U/Th for tephra chronologies (Farley etal., 2002); development ofmicrotephra stratigraphy (Freibel, 2008); measurements of iridium flux (Gabrielli et al., 2004); and stable isotope correlations with speleothems (Lorrey et al., 2008). A new method of ice core dating being explored involves $\mathrm{N}_{2} / \mathrm{O}_{2}$ variations in the ice at Dome Fuji tuned to local insolation at $70^{\circ} \mathrm{S}$ (a method that assumes no lag between insolation forcing and the $\mathrm{N}_{2} / \mathrm{O}_{2}$ response; Kawamura et al., 2007). Such an $\mathrm{N}_{2} / \mathrm{O}_{2}$ timescale is potentially very useful to the combined marine and ice core communities and will likely be adopted if it can be shown that paleointensity can be correlated to cosmonuclides. To be able to apply this to high-resolution sediment studies means that the magnetic paleointensity record has to be systematically developed from marine sections with millennial-scale records. Paleointensity records tend to be better in high latitude/low oxygen environments, and sediment drifts are an ideal archive (Channell et al., 2000). Locations need to be systematically sought out in order to build up paleointensity databases needed for calibration of the Quaternary.

There was considerable discussion over the concept of developing marine 'reference' cores akin to the long ice core records for better global correlation of climate records. The Greenland ice core records have become, almost by default, the de facto "type-section" for late Pleistocene climate change in that they serve as the measuring stick against which other climate records are inevitably compared. One drawback, however, is that the ice cores represent conditions at essentially one location in the high northern

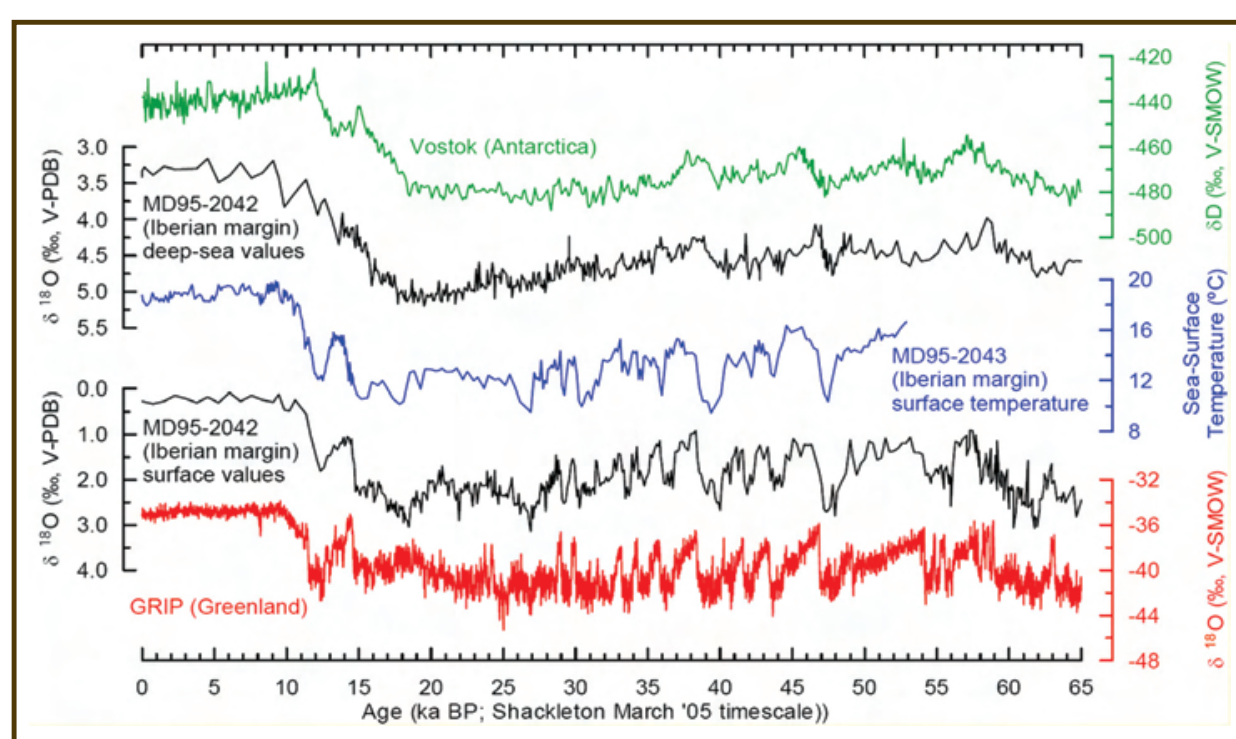

Figure 5. The development of a limited number of well-dated marine 'reference sections' for the late Quaternary would serve as a valuable complement to Greenland and Antarctic ice core records, which by their nature only record high-latitude processes in the two hemispheres. One recommended location for such a reference section is off the southwest coast of Iberia (see no. 35 with 'star' in Fig. 6) near the site of long Calypso cores MD95-2042 and MD95-2043, for which pre-existing data (Shackleton et al., 2000, 2004) have already demonstrated high and uninterrupted sedimentation rates and a clear record of abrupt climate events in the mid-latitudes that can be correlated to those in Greenland. Extending the record at this site to encompass multiple glacial-interglacial cycles can only be accomplished by scientific ocean drilling. latitudes and are inappropriate for study of much of the climate system (Shackleton et al., 2000, 2004). The development of a counterpart series of marine reference sections would require the generation of a few internationally coordinated, multi-replicated, multi-parameter, high-resolution records (Fig. 5; Alley, 2003). However, it was acknowledged that the great size and horizontal and vertical variability in the oceans make identification of a "few" reference sections a difficult task. In selecting the locations for such reference sites, it was felt that drilling targets should be chosen so as to address specific paleoclimatic questions rather than locating them simply to achieve some degree of geographic coverage. For example, a reference section for understanding the MOC might actually consist of a depth 
transect, while reference sections for ENSO could consist of drilled sequences from $\mathrm{El}$ Niño-sensitive areas such as Indonesia or Tahiti. If such a suite of marine reference sections can be developed over time, they will provide marine sediment analogues to the polar ice cores, but will be temporally and spatially more extensive.

As part of the workshop, participants were asked to submit information on potential targets for high-resolution continental and oceanic drilling that satisfied specific requirements of record length and resolution (annual to millen-

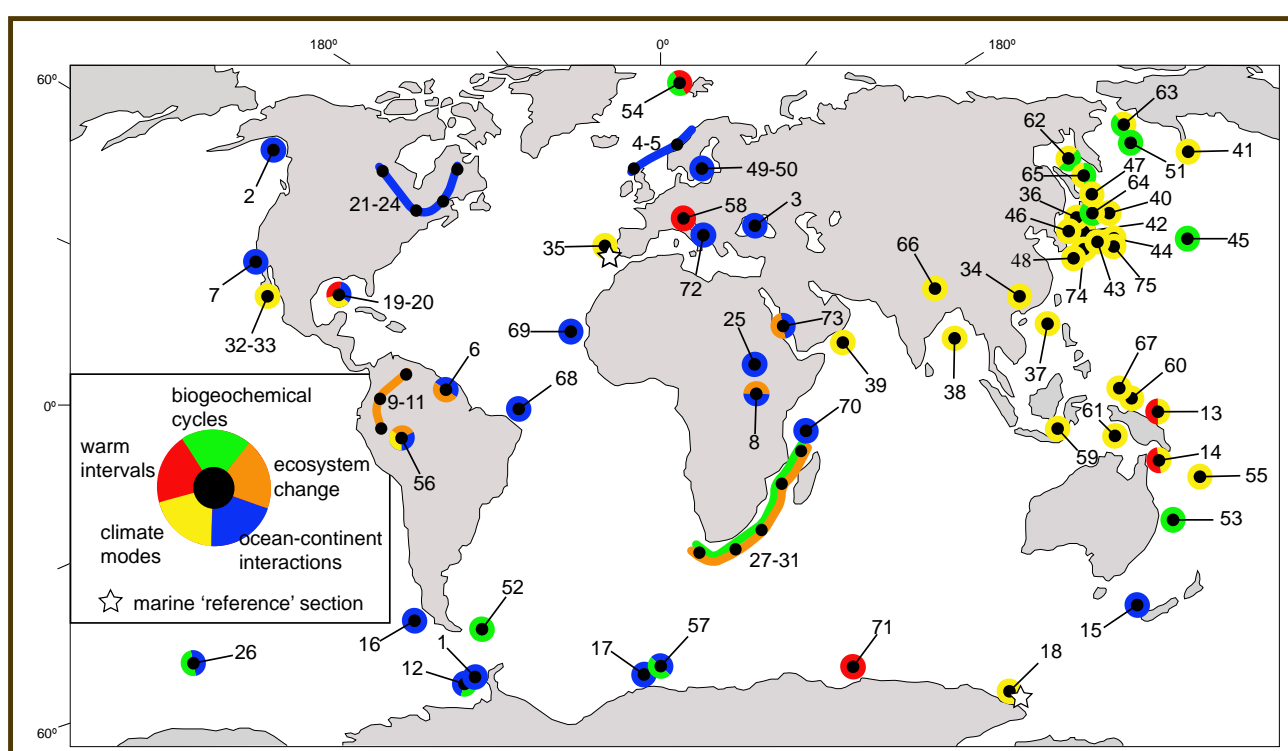

Figure 6. Compilation of potential drilling sites proposed by workshop participants to address the five "petal" themes of the flower diagram shown in Fig. 3. Site numbers are linked to information that can be found in Appendix 1 (http://high-resolutoin.icdp-online.org). nial) and which address questions related to the key research themes highlighted in Fig. 3 and this report. The resulting array of drilling targets, identified in Fig. 6 and keyed there to theme and to the site-specific information listed in Appendix 1, shows that an impressive number of locations are available globally where the potential exists to recover sedimentary sequences suitable for high-resolution study. The themes/targets incorporate many sites already in the review system as part of existing ICDP/IODP drilling proposals (Appendix 1, http://high-resolution.icdp-online. org).

A series of four hypothetical transects emerged from discussions as potential examples of how combined IODP and ICDP drilling could maximize scientific progress in paleoclimate research. These are presented here to illustrate how strategically placed sites can be combined to address broad climate questions and themes.

1) The Core ENSO Signal and Teleconnections. Much can be learned about ENSO and its behavior through time, based on a combined land/sea transect from SE Asia/ Papua New Guinea via Pacific Islands to the west coast of South and Central America. This might incorporate both high deposition rate marine records and drilled coral sequences spanning the tropical Pacific, as well as lakes along the western edge of the Americas. In addition, records from regions such as northeast Brazil, South Africa, and New Zealand that are strongly teleconnected to ENSO today would provide important information as to whether these linkages persist through time under different global boundary conditions.

2.) Baikal to Bengal. A roughly north-south transect was envisioned that would focus on the internal dynamics of the Asian monsoonal system. This would include sites spanning the latitude range from the Siberian arctic
Lake El'gygytgyn to Lake Baikal to the Bengal Fan system, with potential intermediate sites located in the Amur River, the Tibetan Plateau and vicinity, India, and the Ganges Plain. Adding sites in and around the Arabian Sea would broaden the set of addressable questions by tying in regions affected instead by the Indian monsoon.

3.) Southern Hemisphere Tropics (South America) to Southern High Latitude Interactions. Southern hemisphere climate records are currently limited in number, but potential exists to drill latitudinal transects of sites ranging from the southern tropics of South America into the high southern latitudes, both on land and in coastal waters where high sedimentation rate sequences are most likely to be found. It was generally felt that South America offered an important opportunity in the southern hemisphere to develop a comprehensive regional database of sites.

4.) The Bipolar Seesaw, North-South Gradients, and Interhemispheric Linkages. Records from the last glacial indicate that the abrupt warmings and coolings recorded in Greenland ice appear to be out of phase with their counterpart temperature excursions in the high-latitude Southern Hemisphere, an observation consistent with changes in the Atlantic's meridional overturning circulation and its effects on ocean heat transport (EPICA Community Members, 2006). We know little about whether this "bipolar seesaw" is operative at other times in the past and of how changing temperature gradients affect such climatic variables as the distribution of tropical precipitation and ITCZ position. Transects of drill sites on land and in the ocean spanning the high to low latitudes in both hemispheres are the only way to examine how gradients and interhemispheric linkages have varied through time. 
As already noted, workshop participants endorsed the concept of developing a limited number of globally distributed marine reference sections for the purpose of calibrating Quaternary climate at high resolution in key regions. It was recommended that one such early target area should be offshore of the southwest coast of Iberia (Figs. 5, 6) where high sedimentation rates, record continuity, and tight linkages to the rapid climate excursions in Greenland have already been demonstrated. In addition, a large data set of proxy records already exists from this location (Cayre et al., 1999; Sanchez-Goñi et al., 1999; Shackleton et al., 2004; Skinner et al., 2003), so we know that sediments are amenable to analysis using a wide variety of methods.

Proxy data generated from high-resolution geologic archives will seldom lead to an improved understanding of how the climate system works if those data are not linked into modern thinking about climate dynamics and integrated into an Earth-system modeling approach. The presence of modelers at the workshop ensured that data-model integration was a prominent component of the discussions.

\section{Integration of Paleoclimatic Data and Earth-System Modelling}

Over the past years Earth-system modeling has become increasingly important in the area of paleoclimatic research. Specifically, physically based models provide a valuable tool to assess conceptual models of past climate changes derived from paleoclimatic data. In addition, data-based reconstructions of past climate variations provide critical test grounds for Earth-system models that are usually tuned to capture present-day climate. Accordingly, combining data-based reconstructions and paleoclimate modeling offers a promising track to fully comprehend past climate dynamics and to test models used for assessing future climate changes (Ramstein et al., 2007; Mulitza et al., 2008).

Specific benefits that can result from the joint utilization of paleoclimatic reconstructions and paleoclimate modeling include a means for formulating and testing hypotheses (e.g., by quantifying the response of the climate system to known or potential forcings). Moreover, climate models provide a comprehensive framework for exploring couplings and feedbacks between the various components of the climate system. This type of analysis is of special relevance for detecting thresholds in the climate system. Finally, Earth-system models offer a link between past climate changes and projections of future climate, which is assessed by the same type of models.

The combination of paleoclimatic reconstructions and Earth-system modeling is thus very forward-looking with respect to disentangling climate dynamics on timescales of societal relevance. Both IODP and ICDP have the obligation to underpin the efforts of the IPCC in reducing the uncertainties associated with the projections of future climate changes. A pivotal contribution of paleoclimatic reconstructions arises through the possibility of testing IPCC-type Earth-system models beyond the range of climate variability documented by the instrumental record. A research strategy following this path would involve modelers from the early planning stage of an IODP or ICDP project. Such collaboration would not only allow for setting up joint hypotheses to be tested but also to choose drilling locations most sensitive to specific climate changes.

\section{Summary and Recommendations}

The Potsdam workshop attracted an overwhelming response from the paleoclimate community, and the enthusiastic discussions and debates that took place clearly demonstrated that the topic of scientific drilling of high-resolution archives is hot, timely, and widely interesting to the scientific community. Great synergy already exists between IODP and ICDP in the field of paleoclimate research. Workshop participants clearly felt that having these two programs work together to jointly address the key research themes identified in Potsdam (the "petals" of Fig. 3) is the most promising way forward.

We recommend that further strengthening of the links between IODP and ICDP be a goal of the leadership of both programs. Each program brings state-of-the-art drilling technology to bear on scientific questions that only these programs-and the research communities they supportcan answer. Cooperation should also be sought with other major programs devoted to paleoclimate sampling, including IPICS (International Partnership for Ice Core Sciences) and IMAGES (International Marine Global Change Study). Climate, by its very nature, is a complex system, and neither land-based nor marine-based records are sufficient by themselves to provide a complete picture of the system's workings through time.

Closer cooperation between IODP and ICDP ideally should be extended to have standard procedures for core processing and treatment, agreed-upon suites of standard measurements and protocols, policies for data integration, and perhaps even common curation of cores. One obvious indication of a closer working relationship between the programs-and that would seem simple to achieve-would be to have site locations for ICDP drilling and links to the data included on the searchable online IODP digital site map. This would facilitate planning efforts for some of the large-scale transect opportunities envisioned at this workshop.

Continued development of drilling capabilities should be a high priority. Within ICDP, there seems to be a gap in drilling technology for the recovery of sediments between about 20 $\mathrm{m}$ and $100 \mathrm{~m}$ penetration (i.e., what can be achieved with standard piston coring and by deep drilling using the GLAD rig). We should also further explore the possibility of 
increasing core diameters in both programs to allow for larger sediment volumes for multi-proxy studies. Finally, increased flexibility in the duration of drilling campaigns, especially within IODP, would greatly facilitate the planning and proposal process for many high-resolution sites where sediments can often be recovered relatively quickly and efficiently.

The Potsdam workshop left no doubt that scientific drilling is absolutely critical to the future of paleoclimate research. The large array of potential drilling targets summarized here, together with the concept of transects and climate reference sections put forth, should ensure that high-resolution records appropriate for investigating the climate research themes identified in this report are available to the community at large.

\section{Acknowledgements}

The workshop Steering Committee thanks IODP and ICDP for their generous financial support of this workshop and our friendly hosts at GFZ-Potsdam for their care and attention. Thanks also go to Benjamin Flower, Mark Bush, Paul Baker, and Robert Dunbar for their contributions to the thematic summaries, and to the keynote speakers, discussion leaders, and volunteer reporters who kept diligent notes. Finally, we are grateful to all of the workshop participants for sharing their time, expertise and great enthusiasm for paleoclimate science.

\section{References}

Alley, R.B., 2003. Raising paleoceanography. Paleoceanography, 18:1085, doi:10.1029/2003PA000942.

Baker, P.A., Rigsby, C.A., Seltzer, G.O., Fritz, S.C., Lowenstein, T.K., Bacher, N.P., and Veliz, C., 2001. Tropical climate changes at millennial and orbital timescales on the Bolivian Altiplano. Nature, 409:698-701, doi:10.1038/35055524.

Bartov, Y., Goldstein, S.L., Stein, M., and Enzel, Y., 2003. Catastrophic arid perturbations of the East-Mediterranean climate linked to the North Atlantic Heinrich Events. Geology, 31:439-442, doi:10.1130/0091-7613(2003)031<0439:CAEITE >2.0.CO;2.

Behl, R.J., and Kennett, J.P., 1996. Brief interstadial events in the Santa Barbara Basin, NE Pacific, during the past $60 \mathrm{kyr}$. Nature, 379:243-246, doi:10.1038/379243a0.

Bender, M., Sowers, T., and Labeyrie, L., 1994. The Dole effect and its variations during the last 130,000 years as measured in the Vostok ice core. Global Biogeochem. Cycles, 8:363-376, doi:10.1029/94GB00724.

Bintanja, R., and van de Wal, R.S.W., 2008. North American ice-sheet dynamics and the onset of 100,000-year glacial cycles. Nature, 454:869-872, doi:10.1038/nature07158.

Brigham-Grette, J., Melles, M., Minyok, P., and Scientific Party, 2007. Overview and significance of a $250 \mathrm{ka}$ paleoclimate record from El'gygytgyn Crater Lake, NE Russia. J. Paleolimnol., 37:1-16, doi:10.1007/s10933-006-9017-6.

Broecker, W.S., 2006. Abrupt climate change revisited. Global Planet. Change, 54:211-215, doi:10.1016/j.gloplacha.2006.06.019.
Cao, M., and Woodward, F.I., 1998. Dynamic responses of terrestrial ecosystem carbon cycling to global climate change. Nature, 393:249-252, doi:10.1038/30460.

Cayre, O., Lancelot, Y., and Vincent, E., 1999. Paleoceanographic reconstructions from planktonic foraminifera off the Iberian Margin: temperature, salinity and Heinrich events. Paleoceanogr., 14:384-396, doi:10.1029/1998PA900027.

Channell, J.E.T., Stoner, J.S., Hodell, D.A., and Charles, C.D., 2000. Geomagnetic paleointensity for the last $100 \mathrm{kyr}$ from the sub-Antarctic South Atlantic: a tool for inter-hemispheric correlation.Earth Planet. Sci.Lett., 175:145-160, doi:10.1016/ S0012-821X(99)00285-X.

Cheddadi, R., de Beaulieu, J.L., Jouzel, J., Andrieu-Ponel, V., Laurent, J.M., Reille, M., Raynaud, D., and Bar-Hen, A., 2005. Similarity of vegetation dynamics during interglacial periods. Proc. Natl. Acad. Sci. U.S.A., 102(39):13939-13943, doi:10.1073/pnas.0501752102.

Clarke, G.K.C., 2005. Subglacial processes. Ann. Rev. Earth Planet. Sci., 33:247-276, doi:10.1146/annurev.earth.33.092203. 122621.

Clement, A.C., and Peterson, L.C., 2008. Mechanisms of abrupt climate change of the last glacial period. Rev. Geophys., 46:RG4002, doi:10.1029/2006RG000204.

Cramer, W., Bondeau, A., Woodward, F.I., Prentice, I.C., Betts, R.A., Brovkin, V., Cox, P.M., Fisher, V., Foley, J.A., Friend, A.D., Kucharik, C., Lomas, M.R., Ramankutty, N., Sitch, S., Smith, B., White, A., and Young-Molling, C., 2001. Global response of terrestrial ecosystem structure and function to $\mathrm{CO}_{2}$ and climate change: results from six dynamic global vegetation models. Global Change Biol., 7:357-373, doi:10.1046/j.1365-2486.2001.00383.x.

Dansgaard, W., Johnsen, S.J., Clausen, H.B., Dahl-Jensen, D., Gundestrup, N., and Hammer, C.U., 1984. North Atlantic climatic oscillations revealed by deep Greenland ice cores. In Hansen, J.E., and Takahashi, T. (Eds.), Climate Processes and Climate Sensitivity, Geophys. Monogr. Ser., 29, Washington, DC (American Geophysical Union), 288-298.

Dansgaard, W., Johnsen, S., Clausen, H.B., Dahl-Jensen, D., Gundestrup, N.S., Hammer, C.U., Hvidberg, C.S., Steffensen, J., Sveinbjörnsdottir, A.E., Jouzel, J., and Bond, G., 1993. Evidence for general instability of past climate from a 250-kyr ice core record. Nature, 364:218-220, doi:10.1038/ $364218 \mathrm{a} 0$.

deMenocal, P., 2004. African climate change and faunal evolution during the Pliocene/Pleistocene. Earth Planet. Sci. Lett., 220:3-24, doi:10.1016/S0012-821X(04)00003-2.

EPICA Community Members, 2004. Eight glacial cycles from an Antarctic ice core. Nature, 429:623-628, doi:10.1038/ nature02599.

EPICA Community Members, 2006. One-to-one coupling of glacial climate variability in Greenland and Antarctica. Nature, 444:195-198, doi:10.1038/nature05301.

Fabry, V.J., Seibel, B.A., Feely, R.A., and Orr, J.C., 2008. Impacts of ocean acidification on marine fauna and ecosystem processes. ICES J. Mar. Sci., 65:414-432, doi:10.1093/icesjms/ fsn048.

Farley, K.A., Kohn, B.P., and Pillans, B., 2002. The effects of secular disequilibrium on (U-Th)/He systematics and dating of Quaternary volcanic zircon and apatite. Earth Planet. Sci. 
Lett., 201:117-125, doi:10.1016/S0012-821X(02)00659-3.

Freibel, C.G.S., 2008.Microstratigraphy of the Kibish hominin sites KHS and PHS, lower Omo Valley, Ethiopia. J. Hum. Evol., 55:404-408.

Gabrielli, P., Barbante, C., Plane, J.M.C., Varga, A., Hong, S., Cozzi, G., Gaspari, V., Planchon, F.A.M., Cairns, W., Ferrari, C., Crutzen, P., Cescon, P., and Boutron, C.F., 2004. Meteoric smoke fallout over the Holocene epoch revealed by iridium and platinum in Greenland ice. Nature, 432:1011-1014, doi:10.1038/nature03137.

Gregory, J.M., Huybrechts, P., and Raper, S.C.B., 2004. Climatology: threatened loss of the Greenland ice sheet. Nature, 428:616, doi:10.1038/428616a.

Haug, G.H., Günther, D., Peterson, L.C., Sigman, D.M., Hughen, K.A., and Aeschliman, B., 2003. Climate and the collapse of Maya civilization. Science, 299:1731-1735, doi:10.1126/ science.1080444.

Hendy, I.L., and Kennett, J.P., 2000. Dansgaard-Oeschger cycles and the California Current system: planktonic foraminiferal response to rapid climate change in Santa Barbara Basin, Ocean Drilling Program Hole 893A. Paleoceanogr., 15:30-42, doi:10.1029/1999PA000413.

Hodell, D.A., Anselmetti, F.S., Ariztegui, D., Brenner, M., Curtis, J.H., Gilli, A., Grzesik, D.A., Guilderson, T.J., Müller, A.D., Bush, M.B., Correa-Metrio, A., Escobar, J., and Kutterolf, S., 2008. An 85-ka record of climate change in lowland CentralAmerica.Quat. Sci.Rev.,27:1152-1165, doi:10.1016/j. quascirev.2008.02.008

Hu, A., Meehl, G., Han, W., and Yin, J., 2009. Transient response of the MOC and climate to potential melting of the Greenland Ice Sheet in the 21st century. Geophys. Res. Lett., 36:L10707, doi: 10.1029/2009GL037998.

Huang, Y., Clemens, S.C., Liu, W., Wang, Y., and Prell, W.L., 2007. Large-scale hydrological change drove the late Miocene $\mathrm{C} 4$ plant expansion in the Himalayan foreland and Arabian Peninsula. Geology, 35:531-534, doi:10.1130/G23666A.1.

Hughen, K., Lehman, S., Southon, J., Overpeck, J., Marchal, O., Herring, C., and Turnbull, J., 2004. ${ }^{14} \mathrm{C}$ activity and global carbon cycle changes over the past 50,000 years. Science, 303:202-207, doi:10.1126/science.1090300.

IPCC, 2007. Climate Change 2007: Synthesis Report. Contribution of Working Groups I, II and III to the Fourth Assessment Report of the Intergovernmental Panel on Climate Change [Pachauri, R.K., and Reisinger, A. (Eds.)], Geneva, Switzerland (Intergovernmental Panel on Climate Change), 104 pp.

Kawamura, K., Parrenin, F., Lisiecki, L., Uemura, R., Vimeux, F., Severinghaus, J.P., Hutterli, M.A., Nakazawa, T., Aoki, S., Jouzel, J., Raymo, M.E., Matsumoto, K., Nakata, H., Motoyama, H., Fujita, S., Goto-Azuma, K., Fujii, Y., and Watanabe, O., 2007. Northern Hemisphere forcing of climatic cycles in Antarctica over the past 360,000 years. Nature, 448:912-917, doi:10.1038/nature06015.

Keenlyside, N.S., Latif, M., Jungclaus, J., Kornblueh, L., and Roeckner, E., 2008. Advancing decadal-scale climate prediction in the North Atlantic sector. Nature, 453:84-88, doi:10.1038/ nature06921.

Koeberl, C., Milkereit, B., Overpeck, J.T., Scholz, C.A., Amoako, P.Y.O., Boamah, D., Danuor, S., Karp, T., Kueck, J., Hecky,
R.E., King, J.W., and Peck, J.A., 2007. An international and multidisciplinary drilling project into a young complex impact structure: the 2004 ICDP Bosumtwi Crater Drilling Project - An overview. Meteor.Planet. Sci., 42:483-511.

Kraus, M.J., and Riggins, S., 2007. Transient drying during the Paleocene-Eocene Thermal Maximum (PETM): analysis of paleosols in the Bighorn Basin, Wyoming. Palaeogeogr., Palaeoclimatol., Palaeoecol., 245:444-461, doi:10.1016/j. palaeo.2006.09.011.

Lisiecki, L.E., and Raymo, M.E., 2005. A Pliocene-Pleistocene stack of 57 globally distributed benthic $\delta^{18} \mathrm{O}$ records. Paleoceanogr., 20, PA1003, doi:10.1029/2004PA001071.

Lorrey, A., Williams, P., Salinger, J., Martin, T., Palmer, J., Fowler, A., Zhao, J-X., and Neil, H., 2008. Speleothem stable isotope records interpreted within a multi-proxy framework and implications for New Zealand palaeoclimate reconstruction. Quat. Int., 187:52-75, doi:10.1016/j.quaint.2007.09.039.

Loulergue, L., Schilt, A., Spahni, R., Masson-Delmotte, V., Blunier, T., Lemieux, B., Barnola, J.M., Raynaud, D., Stocker, T.F., and Chappellaz, J., 2008. Orbital and millennial-scale features of atmospheric CH4 over the past 800,000 years. Nature, 435:383-386, doi:10.1038/nature06950.

Mantua, N.J., and Hare, S.R., 2002. The Pacific Decadal Oscillation.J. Oceanogr., 58:35-44, doi:10.1023/A:1015820616384.

Mulitza, S., Prange, M., Stuut, J.-B., Zabel, M., von Doboneck, T., Itambi, A.C., Nizou, J., Schulz, M., and Wefer, G., 2008. Sahel megadroughts triggered by glacial slowdowns of Atlantic meridional overturning. Paleoceanogr., 23:PA4206, doi: 10.1029/2008PA001637.

Parmesan, C., 2006. Ecological and evolutionary responses to recent climate change. Ann. Rev. Ecol. Evol. Syst., 37:637-669, doi:10.1146/annurev.ecolsys.37.091305.110100

Peterson, L.C., Haug, G.H., Hughen, K.A., and Rohl, U., 2000. Rapid changes in the hydrologic cycle of the tropical Atlantic during the last glacial. Science, 290:1947-1951, doi:10.1126/ science.290.5498.1947.

Ramstein, G., Kageyama, M., Guiot, J., Wu, H., Hély, C., Krinner, G., and Brewer, S., 2007. How cold was Europe at the Last Glacial Maximum? A synthesis of the progress achieved since the first PMIP model-data comparison. Clim. Past, 3:331-339.

Rich, J., Stokes, S., Wood, W., and Bailey, R., 2003. Optical dating of tufa via in situ aeolian sand grains: A case example from the Southern High Plains, USA. Quat. Sci. Rev., 22:1145-1152, doi:10.1016/S0277-3791(03)00021-0.

Ruddiman, W.F., 2005. Cold climate during the closest Stage 11 ana$\log$ to recent millennia. Quat. Sci. Rev., 24:1111-1121, doi:10.1016/j.quascirev.2004.10.012.

Sanchez-Goñi, M.F., Eynaud, F., Turon, J.L., and Shackleton, N.J., 1999. High resolution palynological record off the Iberian margin: direct land-sea correlation for the Last Interglacial complex. Earth Planet. Sci. Lett., 171:123-137, doi:10.1016/ S0012-821X(99)00141-7.

Schefuss, E., Schouten, S., and Schneider, R.R., 2005. Controls on central African hydrology during the past 20,000 years. Nature, 437:1003-1006, doi:10.1038/nature03945.

Scholz, C.A., Johnson, T.C., Cohen, A.S., King, J.W., Peck, J.A., Overpeck, J.T., Talobot, M.R., Brown, E.T., Kalindekafe, L., Amoako, P., Lyons, R.P., Shanahan, T.M., Castañeda, I.S., 
Heil, C.W., Forman, S.L., McHargue, L.R., Beuning, K.R., Gomez, J., and Pierson, J., 2007. East African megadroughts between 135 and 75 thousand years ago and bearing on early-modern human origins. Proc. Natl. Acad. Sci. U.S.A., 104(42):16416-164211, doi: 10.1073/pnas.0703874104.

Shackleton, N.J., Hall, M.A., and Vincent, E., 2000. Phase relationships between millennial-scale events 64,000-24,000 years ago. Paleoceanogr., 15:565-569, doi:10.1029/2000PA000513.

Shackleton, N.J., Fairbanks, R.G., Chiu, T.-C., and Parrenin, F., 2004. Absolute calibration of the Greenland time scale: implications for Antarctic time scales and for $\Delta^{14}$ C. Quat. Sci. Rev., 23:1513-1522, doi:10.1016/j.quascirev.2004.03.006.

Shanahan, T.M., Overpeck, J.T., Anchukaitis, K.J., Beck, J.W., Cole, J.E., Dettman, D.L., Peck, J.A., Scholz, C.A., and King, J.W., 2009. Atlantic forcing of persistent drought in West Africa. Science, 324:377-380. doi: 10.1126/science.1166352.

Skinner, L.C., Shackleton, N.J., and Elderfield, H., 2003. Millennialscale variability of deep-water temperature and $\delta^{18} \mathrm{O}_{\mathrm{dw}}$ indicating source variations in the northeast Atlantic, 0-34 cal. Ka BP. Geochem. Geophys. Geosyst., 4:1098, doi:10.1029/2003GC000585.

Stanford, J.D., Rohling, E.J., Hunter, S.E., Roberts, A.P., Rasmussen, S.O., Bard, E., McManus, J., and Fairbanks, R.G., 2006. Timing of meltwater pulse $1 \mathrm{a}$ and climate responses to meltwater injections. Paleoceanogr., 21:PA4103, doi: 1029/ 2006PA001340.

Stevens, T., Armitage, S.J., Lu, H., and Thomas, D.S.G., 2007. Examining the potential of high sampling resolution OSL dating of Chinese loess. Quat. Geochronol., 2:15-22, doi:10.1016/j.quageo.2006.03.004.

Tudhope, A.W., Chilcott, C.P., McCulloch, M.T., Coo, E.R., Chappell, J., Ellam, R.M., Lea, D.W., Lough, J.M., and Shimmield, G.B., 2001. Variability in the El Niño-Southern Oscillation through a glacial-interglacial cycle. Science, 291:1511-1517, doi:10.1126/science.1057969.

Tzedakis, P.C., Hoogheimstra, H., and Pälike, H., 2006. The last 1.35 million years at Tenaghi Philippon: revised chronostratigraphy and long-term vegetation trends. Quat. Sci. Rev., 25:3416-3430, doi:10.1016/j.quascirev.2006.09.002.

Voelker, A.H.L., 2002. Global distribution of centennial-scale records for marine isotope stage (MIS) 3: a database. Quat. Sci. Rev., 21:1185-1212, doi:10.1016/S0277-3791(01)00139-1.

Wang, P., Clemens, S., Beaufort, L., Braconnot, P., Ganssene, G., Jian, Z., Kershaw, P., and Sarnthein, M., 2005. Evolution and variability of the Asian monsoon system: state of the art and outstanding issues. Quat. Sci. Rev., 24:595-629, doi:10.1016/j.quascirev.2004.10.002.

Wang, X., Auler, A.S., Edwards, R.L., Cheng, H., Ito, E., and Solheid, M., 2006. Interhemispheric anti-phasing of rainfall during the last glacial period. Quat. Sci. Rev., 25:3391-3403, doi:10.1016/j.quascirev.2006.02.009.

Wang, Y.J., Cheng, H., Edwards, R.L., An, Z.S., Wu, J.Y., Shen, C.-C., and Dorale, J.A., 2001. A high-resolution absolute-dated late Pleistocene monsoon record from Hulu Cave, China. Science, 294:2345-2348, doi:10.1126/science.1064618.

Weijers, J.W.H., Schouten, S., Sluijs, A., Brinkhaus, H., and Sinninghe Damsté, J.S., 2007. Warm Arctic continents during the Palaeocene-Eocene thermal maximum. Earth Planet. Sci. Lett., 261:230-238, doi:10.1016/j.eps1.2007.06.033.
Wilson, P.A., and Norris, R.D., 2001. Warm tropical ocean surface and global anoxia during the mid-Cretaceous period. Nature, 412:425-429, doi:10.1038/35086553.

Yancheva, G., Nowaczyk, N.R., Mingram, J., Dulski, P., Negendank, J., Liu, J., Sigman, D.M., Peterson, L.C., and Haug, G.H., 2007. Influence of the intertropical convergence zone on the East Asian monsoon. Nature, 445:74-77, doi:10.1038/ nature 05431 .

Zachos, J.C., Röhl, U., Schellenberg, S.A., Sluijs, A., Hodell, D.A., Kelly, D.C., Thomas, E., Nicolo, M., Raffi, I., Lourens, L.J., McCarren, H., and Kroon, D., 2005. Rapid acidification of the ocean during the Paleocene-Eocene Thermal Maximum. Science, 308:1611-1615, doi:10.1126/science.1109004.

\section{Authors (Workshop Steering Committee)}

Juergen Thurow, Department of Earth Sciences, University College London, Gower Street, London, WC1E 6BT, U.K., e-mail: j.thurow@ucl.ac.uk.

Larry C. Peterson, Rosenstiel School of Marine and Atmospheric Science, University of Miami, 4600 Rickenbacker Causeway, Miami, Fla., 33149, U.S.A., e-mail: lpeterson@rsmas.miami.edu.

Ulrich Harms, International Continental Scientific Drilling Program, GFZ German Research Centre for Geosciences, Telegrafenberg, 14473, Potsdam, Germany.

David A. Hodell, Department of Earth Sciences, University of Cambridge, Cambridge, CB2 3EQ, U.K.

Heather Cheshire, Department of Earth Sciences, University College London, Gower Street, London, WC1E 6BT, U.K.

Michael Schulz, Faculty of Geosciences/Center for Marine Environmental Research (MARUM), University of Bremen, D-28334, Bremen, Germany.

Hans-Juergen Brumsack, Institute for Chemistry and Biology of the Marine Environment (ICBM), University of Oldenburg, P.O. Box 2503, D-26111, Oldenburg, Germany.

Tomohisa Irino, Faculty of Environmental Earth Science, Hokkaido University, Kita 10, Nishi 5, Kita-ku, Sapporo, 0600810, Japan.

Valerie Masson-Delmotte, Laboratoire des Sciences du Climat et de l'Environnement, IPSL/CEA-CNRS UMR 1571, Gif-sur-Yvette, France.

Ryuji Tada, Department of Earth and Planetary Science, Graduate School of Science, University of Tokyo, Science Bldg. No.1-734, 7-3-1 Hongo, Bunkyo-ku, Tokyo, 113-0033, Japan.

\section{Related Web Links}

http://www.iodp.org/climate-ws-workshop/

http://www.iodp.org

http://www.icdp-online.org

http://high-resolution.icdp-online.org

\section{Figure Credits}

Fig. 3 - Ben Flower (College of Marine Science, University of South Florida, St. Petersburg, U.S.A) 